RESEARCH ARTICLES

\title{
Developing and perfecting universal cognitive skills of students through integrating scientific knowledge about information in the learning content
}

\section{Desarrollo y mejora de las habilidades cognitivas universales de los estudiantes mediante la integración del conocimiento científico de la información en el contenido de la educación}

\author{
Tsibizova Oksana \\ Russian State Agrarian University - Moscow Timiryazev Agricultural Academy, \\ Moscow, Russian Federation \\ ORCID: https://orcid.org/0000-0003-0674-7140 \\ Galankina Inna \\ Russian State Agrarian University - Moscow Timiryazev Agricultural Academy, \\ Moscow, Russian Federation \\ ORCID: https://orcid.org/0000-0003-2702-0581 \\ Parshina Margarita* \\ Peoples' Friendship University of Russia (RUDN University), Moscow, Russian \\ Federation \\ ORCID: https://orcid.org/0000-0003-1605-5244

\section{Tsupikova Elena} \\ Siberian State Automobile and Highway Academy, Omsk, Russian Federation \\ ORCID: https://orcid.org/0000-0002-7849-4843
}

*Correspondencia

Email: ParshinaMargarita@gmail.com
Citar como:

Tsibizova, O., Galankina, I., Parshina, M., \& Tsupikova,

E. (2021). Developing and perfecting universal cognitive skills of students through integrating scientific knowledge about information in the learning content, 9(SPE2), e1023. Doi: http://dx.doi.org/10.20511/pyr2021.v9nSPE2.1023 


\section{Summary}

The article substantiates the need to integrate the findings of linguistics and information theory for the selection of learning content aimed at developing and perfecting the universal cognitive skills of students of a technical university. Consideration of the concept of information in the learning process, the amount of information, and the quality of information may reveal new insights into the information processes produced by an individual in communication. The authors of the article understand the information process as an action with textual information, leading to its qualitative or formal change with one or another communicative aim.

The learning algorithms for working with textual information, proposed by the authors of the article, allow not only to speed up the process of understanding and consolidating the course content but also provide for a self-reflection component of students' activity, which makes it possible to control, correct and modify the algorithm under the influence of changing communication conditions.

Keywords: Universal cognitive skill, learning content, information, integrating.

\section{Resumen}

El artículo justifica la necesidad de integrar las conclusiones de la lingüística y la teoría de la información para seleccionar el contenido del aprendizaje destinado al desarrollo y mejora de las habilidades cognitivas universales de los estudiantes de la universidad técnica. La consideración en el proceso educativo del concepto de información, la cantidad de información y las cualidades de la información permite una penetración más profunda en la esencia de los procesos de información producidos por el individuo en la comunicación. Los autores del artículo entienden el proceso de información como una acción con información textual que conduce a su cambio cualitativo o formal con un propósito comunicativo particular. Los algoritmos educativos para trabajar con información textual propuestos por los autores del artículo no solo permiten acelerar el proceso de comprensión y consolidación del material de estudio, sino que también proporcionan un componente autorreflexivo de las actividades de los estudiantes, lo que permite controlar, corregir y modificar el algoritmo bajo la influencia de las condiciones cambiantes de la comunicación.

Palabras clave: Capacidad cognitiva universal, contenido de educación, información, integración.

\section{Introduction}

The development of students' thinking is put forward as the main task of modern education, built based on personality-centered approach, competence-based approach, psycholinguistic, psychosemantic, culturological and other approaches. This task stems from the need to master colossal amounts of information with limited time and the available natural abilities of students, and involves restructuring the learning process in accordance with the trends in the integration of sciences, algorithmicization of educational processes and the development of students' creative thinking, which will allow them to modify the obtained algorithms, taking into account changing conditions and tasks.

\section{Methodological basis}

The methodological basis of the study was:

- the method of complex theoretical analysis of the phenomenon studied (theoretical analysis of scientific and educational literature on research issues); 

teachers);

- survey and diagnostic methods (survey, conversation, questioning of students and

- observational methods (direct, indirect, included observation of the process of teaching a language at a technical university to discover reserves to ensure the optimal assimilation of the material);

- the method of modeling the learning process based on optimization technology, considering the psychological, pedagogical and mental patterns of the course of students' learning activities;

- the method of experimental pedagogical research;

- the method of quantitative and qualitative assessment of research results, as well as systemic and comparative analysis.

The aim of the article is to determine and substantiate the composition of universal cognitive skills and the complex of corresponding developmental educational tasks based on the theory of interiorization and the theory of inner speech, according to which: speech, developing in unity with thinking, serves as an indicator of the development of students' cognitive abilities, based on scientific literature and our own scientific research - also the most reliable means of this development. Achieving this aim will significantly optimize the assimilation of large volumes of information with a preliminary determination of its qualitative characteristics (such as reliability, applicability, utility, etc.) and quantitative indicators (completeness, redundancy, insufficiency).

\section{Formulating of problem}

Achieving this aim required the following tasks:

1) to describe the essence of the speech-and-thinking process as a sequential interiorization of information and exteriorization of the semantic content of thinking on the basis of scientific literature and our own research, to propose a slightly improved algorithm for processing incoming information into the structures of a universal subject code in the learning process;

2 ) to describe the conditions for the effectiveness of the formation of new concepts from the standpoint of the theory adopted as a basis;

3) to present an exhaustive composition of cognitive universal educational skills involved in the educational process and representing the basis for planning and implementing practical acts of students - vocal and physical; learning;

4) to present the criteria for the selection of learning content, principles and conception of

5) to present the process of determining the content of training in a specific discipline, taking into account the sequence of mastering information by students with self-reflective accompaniment of their cognitive universal educational skills;

6) to indicate the results of the experimental work.

\section{Discussion}

\section{The main part of the article}

Scientists and educators, starting with L.S. Vygotsky, declare a close relationship and even fusion of the processes of development of speech and thinking (I.Ya. Lerner, A.N. Leont'ev, etc.), in connection with which they note the need to determine the learning content in such a way that it has a beneficial effect on the development of speech-and-thinking activity of students and effectively directed this development (I.A. Zimnyaya, L.P. Vladimirova, Ya.A. Pavlova, I.A. Petukhova).

The content of any subject forms the student's mental activity due to the direct participation of speech in the learning process, however, it is quite realistic to improve, strengthen, due to the content of the academic subject, the formation and development of students' speech-and-thinking activity, for example, by integrating the theoretical provisions of the sciences of information and linguistics (N.I. Zhinkin, A.N. Kolmogorov, K. Shennon). 
Since the generation of speech involves the active participation of all components of the speech-and-thinking process, special attention should be paid to internal speech as an intermediary between thinking and external speech, its structure and features of functioning, since it is internal speech that determines the success of all speech-and-thinking activity (M.K. Artyna, E.V. Kashirskaya and others). It is in the field of internal speech that orientation (including control) occurs, while execution refers to the stage of external speech action (Galperin, 1959, p. 441-169).

Illustrative in this regard is the process of forming a concept in a student. At the stage of orientation, the communicant recognizes an object or phenomenon, assigns it to a certain class or category based on the results of studying the main features of the object / phenomenon, inscribes the concept into the conceptual picture of reality available in the experience and checks the consistency and accuracy of this inclusion. Thus, at the stage of orientation, mental operations of analysis, classification, categorization, systematization and synthesis are performed. At the stage of execution, the results obtained are verbalized in the form of an interpretation of a concept or an educational text, which requires the use of mental operations of synthesis and analysis through synthesis.

Galperin developed hypothesis that the signs of a concept do not exhaust its content; it is necessary to investigate the function that is performed by the objects / phenomena corresponding to the concept. You can formulate this idea differently: for a full-fledged learning of a concept, it must be included in a system of connections that describe both its functions and its relationship to various kinds of related concepts.

All relationships of concepts can be represented in the form of a spatial, temporal or logical scheme, which, in general, should take place at the stage of orientation - the formation of a universal subject code, in the form of which the acquired knowledge is stored in thinking. More precisely, the construction of a universal subject code is a means of independent acquisition of experience based on the information obtained and studied. Operating with such schemes can be considered the main function of inner speech.

But not every scheme is applicable in certain specific conditions without transformation or modification under the influence of new information. This statement is especially indicative for speech activity, in which ready-made stereotyped communication formulas need to be clarified for a speech situation or type of communication (constructive / destructive). The scheme available in the communicant's experience must be filled with specific content (Tsupikova, 2014, p. 197201).

For an adequate operation of concepts, therefore, it is necessary:

- to analyze the situation from the point of view of conditions essential for achieving the aim;

- to schematize the situation in order to transfer it to the internal plan and search for a place for this scheme in the experience;

- to compare the schemes available in the experience and to derive the most suitable for specific conditions;

- to fill the scheme with specific content;

- to determine options for a specific formalization of the scheme;

- to analyze the system of options in order to select the most adequate and effective for the given conditions.

The consecution of actions requires deep reflection and completion of the student's cognitive mechanisms, while the definition of the system of theoretical concepts of the academic discipline serves as a starting point for the implementation of internal and external speech-andthinking actions of the student. The effectiveness of their work is determined by the ability and desire to work independently with different sources of information; striving for self-esteem, selfcontrol and self-correction of their results.

No doubt these are problems of an interdisciplinary nature, but within the framework of a separate academic subject it is necessary to find ways to solve them by methods of this particular discipline.

The basis for the construction of criteria for assessing students' academic work is the verbalization of self-reflexive analysis. Verbalization can be organized in the form of performing 
tasks of a search nature, the structure of which is traditionally described as "a condition - a linguistic / speech fact - a specific problem - questions that direct the sequence of students' actions leading to a solution to the problem".

The learning content is considered from the point of view of pedagogical principles, as a system of initial requirements that ensure the success of the learning process. The principles of teaching allow to reveal in detail and meaningfully the goals of teaching, serve as criteria for assessing the effectiveness of pedagogical interaction, and are used to determine the structure of the educational process.

For the content of student-centered learning, the principles of accessibility are significant; development of abilities, accounting and development of inclinations; self-determination in cognition; consciousness and activity of students; sovereignty in knowledge; humanization of education; democratization; humanization; connection of theory with practice.

The criteria that form a general didactic system can also be taken as a tool for determining the learning content and the principle of selecting sources for it: the holistic reflection in the learning content of the tasks of forming a student's creative, independent thinking; correspondence of the complexity of the educational material to the educational capabilities of students; correspondence of the volume of educational material to the time allocated for the study of the discipline; high scientific and practical value of the educational material.

The effectiveness of determining the learning content aimed at developing universal cognitive skills is revealed in the course of experimental work according to the following criteria:

1) Personal-semantic attitude of the student to the content of the discipline, an indicator of which can be the intensity of the student's cognitive need for the content of the subject.

2) The formation of the methods of cognition is assessed by the ability of students to carry out educational research work and the success of its implementation.

We present the procedure for selecting the learning content for the disciplines "Russian language and speech culture" and "Foreign language".

As a basis for determining the learning content, based on the set aim, we take a group of cognitive universal educational actions; to assess the success of their formation, we use criteria based on the communicative and self-reflective skills of students (Scheme 1).

\begin{tabular}{|c|c|}
\hline \multicolumn{2}{|r|}{ Cognitive universal learning skills } \\
\hline \multirow{6}{*}{ 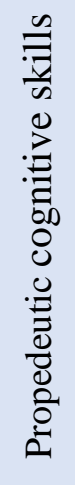 } & a preliminary analysis of the available information \\
\hline & Identifying the problem, creating a challenging situation \\
\hline & arguing the relevance of a challenging situation \\
\hline & selection and formulation of the cognitive task \\
\hline & making assumption as a solution of a challenging situation \\
\hline & $\begin{array}{l}\text { formulation of a hypothesis and disclosure of the concept of the process } \\
\text { of cognition / research }\end{array}$ \\
\hline
\end{tabular}

Scheme 1. Propedeutic cognitive skills

The cognitive skills presented in Scheme 2 during these language disciplines are formed and improved by introducing the topic "Information and knowledge. Information Processes" and students' performance of tasks such as:

1) Explain why is it impossible to transfer knowledge from one person to another?

2) What needs to be done to make the information your own knowledge?

3) How to "transfer" your knowledge to another person? What must the recipient do to make your knowledge his own? 
4) Determine the sequence of implementation of information processes, which gives the most effective result. Prove your point of view.

5) At what stage of the scheme you built (task 4) stand the translation of information into knowledge?

6) Formulate a hypothesis on the topic. Build it according to the structure "The statement is true if the following conditions are met:..." or "If...., Then...".

\begin{tabular}{|c|c|}
\hline$\underset{8}{\stackrel{8}{0}}$ & $\begin{array}{l}\text { search for information for registration of research, assessment of } \\
\text { information sources, selection of thematically necessary information }\end{array}$ \\
\hline$\stackrel{\infty}{\leftrightarrows} .0$ & $\begin{array}{l}\text { determination of quantitative and qualitative characteristics of the selected } \\
\text { information }\end{array}$ \\
\hline$\overline{0}_{0} \bar{d}$ & formulating a problem for discussion \\
\hline ن & $\begin{array}{l}\text { building an activity algorithm while solving problems of a creative and } \\
\text { search nature }\end{array}$ \\
\hline
\end{tabular}

\section{Scheme 2. Cognitive planning}

The cognitive skills presented in Scheme 2 during the disciplines "Russian language and speech culture" and "Foreign language" are formed and improved by introducing the topic "Planning and forecasting. Presupposition and Logic" and student performance of tasks such as:

1) Determine the amount of information in the submitted texts.

2) Explain what is meant by "completeness" of information. Is this an objective characteristic of the text or does it depend on some external factors?

3) Determine the quality of the information in the text below.

4) Give this text the quality of authenticity. What needs to be done for this?

5) Construct false information. What qualities of information are required in such a text the information to be perceived as true?

6) Suggest options for the content of the text, based on its title. Is it possible to predict the content of a newspaper article by reading the title?

\begin{tabular}{|c|c|}
\hline \multirow{7}{*}{ 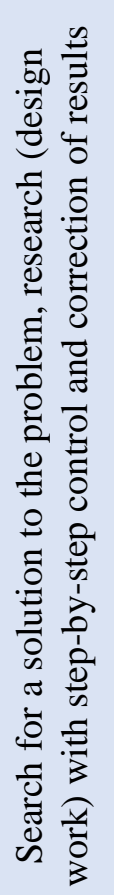 } & Observation and experimentation \\
\hline & Creation, use and transformation of symbolic media \\
\hline & Modelling of phenomena and processes \\
\hline & $\begin{array}{l}\text { Conduct of logical actions and operations (conclusions and inferences, } \\
\text { selection of classification grounds and classification, comparison) }\end{array}$ \\
\hline & Training and learning skills (various learning techniques) \\
\hline & $\begin{array}{l}\text { Knowledge of common techniques and self-quest for solutions to practical } \\
\text { problems }\end{array}$ \\
\hline & Discussion and evaluation of results and their application to new situations \\
\hline
\end{tabular}




\section{Scheme 3. Search for a solution to the problem}

The cognitive skills presented in Scheme 4 during the disciplines "Russian language and speech culture" and "Foreign language" are formed and improved by introducing the topic "Structuring vocabulary. Lexical and logical categories - correlation" and student performance of tasks such as:

1) Build a reference schema showing the composition of systemic lexical relations.

2) What lexical relations correspond to the operations of association, synthesis, analysis?

3) Expand the scheme you built (task 1) into the text.

4) Complete the text with examples and explanations.

5) What are the logical actions of classification, categorization, comparison, analogy?

In the same way, we have investigated such groups of cognitive skills as evaluation of results (development of criteria and scales for evaluating research results, assessment the results of the study, applying results to new situations, formulating new knowledge); independent assimilation of information (assimilation of knowledge and the implementation of its transfer to a new situation, etc.); semantic reading (orientation and perception of texts of different functional styles, extracting the necessary information from the read text at the level of content and meaning, etc.); logical operations (object recognition, highlighting their essential features, comparison, synthesis, analysis, etc.); work with information (orientation in various sources of information; interpretation of information; analysis, assessment of the quality and reliability of the information received, etc.); awareness and independent construction of oral and written speech utterance (planning, implementation of grammatical and semantic implementation of the internal program of speech action, etc.); choice of language means depending on the specific communication situation; structuring information (drawing up a smart map, table, scheme). The corresponding elements of the learning content, contributing to their formation and development, are proposed.

The introduction of these actions into the learning content for the formation of cognitive skills and the skills of their self-reflexive support had the following results:

1) The described process of formation and development of students' cognitive skills ensures the best learning outcomes, that is, they contribute to the optimization of the educational process as a whole.

2) The skills of working with textual information and algorithms for working on the text allowed the students of the experimental groups to significantly reduce the time spent on mastering educational information.

3) Targeted capacity-building of cognitive skills significantly increased the percentage of adequacy of information understanding and the quality of reproduction of text content with elements of interpretation (presuppositions); increased the students correctly identifying communicatively important qualities of information; allowed to teach students to determine the value and applicability of the information received and to make a critical analysis of information. reflection.

4) Clear algorithms for working on the text ensured a conscious desire of students to self-

\section{Conclusion}

The results of the experiment showed the great developmental impact of such work. The experimental learning carried out and the comparison of the results of the ascertaining and final sections confirmed its effectiveness.

Teaching specific disciplines, built on the basis of algorithmicization, the integration of sciences and the development of students' speech-and-thinking activities, makes it possible to clearly define the aim, objectives and learning content, offer students reliable action algorithms for solving groups of challenging situations, methods of self-reflective activity that ensures an objective high quality of the work done, a clear work plan for the teacher. 


\section{Referencias}

Artyna, M.K. (2019) Inner speech as an aspect of verbal and cogitative activity in modern linguistics [Artyna, M.K. Vnutrenniaia rech' kak aspekt rechemyslitel'noi deiatel'nosti $\mathrm{v}$ sovremennoi lingvistike]. The world of science, culture and education [Mir nauki, kul'tury, obrazovaniia], 2 (75), 336-339

Gal'perin, P.Ya. (1959) Development of the research into building mental activity [Gal'perin, P.Ya. Razvitie issledovanii po formirovaniiu umstvennykh deistvii]. Psychological science in the USSR [Psikhologicheskaia nauka v SSSR], Vol. 1, 441-469, Moscow, Russia.

Kashirskaya, E.V. (2013) The role of internal dialogue in the development of speech and mental activity of students - future psychologists [Kashirskaya, E.V. Rol' vnutrennego dialoga $\mathrm{v}$ protsesse formirovaniia rechemyslitel'noi deiatel'nosti studentov budushchikh psikhologov]. Bulletin of the Cherepovets State University [Vestnik Cherepovetskogo gosudarstvennogo universiteta], 46, 128-131.

Kolmogorov, A.N. (1987) Theory of information and theory of algorithms [Kolmogorov, A.N. Teoriya informatsii i teoriia algoritmov], 304, Moscow, Russia.

Leont'ev, A.N. (1975) Activity. Consciousness. Personality [Leont'ev, A.N. Deiatel'nost'. Soznanie. Lichnost'], 304, Moscow, Russia.

Lerner, I.Ya. (1980) Educational process and its regularities. [Lerner, I.Ya. Protsess obucheniia i ego zakonomernosti.] Series: Pedagogy and Education [Seriya: Pedagogika i psikhologiia], 180, Moscow, Russia.

Nikitin, P., Gorokhova, R., Bazhenov, R., Bystrenina, I. (2020). Applied orientation and interdisciplinary integration as a factor in increasing student learning motivation [Nikitin, P., Gorokhova, R., Bazhenov, R., Bystrenina, I. (2020) Prikladnaya napravlennost' $i$ mezhdisciplinarnaya integraciya kak faktor povysheniya uchebnoj motivacii studentov]. Universal Journal of Educational Research, 8(10), 4931-4938

Nikitin, P.V., Bazhenov, R., Bystrenina, I., Kazarenkov, V.I., Gorokhova, R. (2018). New methods of diagnosing the psycho physiological characteristics of students for the organization of adaptive e-learning [Nikitin, P.V., Bazhenov, R., Bystrenina, I., Kazarenkov, V.I., Gorokhova, R. (2018) Novye metody diagnostiki psihofiziologicheskih osobennostej studentov dlya organizacii adaptivnogo elektronnogo obucheniya]. Proceedings of the 32nd International Business Information Management Association Conference, IBIMA 2018 - Vision 2020: Sustainable Economic Development and Application of Innovation Management from Regional expansion to Global Growth, 7825-7831

Pavlova, Ya.A. (2015) Conceptual approaches to the definition of the education content in domestic didactics [Pavlova Ya. A. Kontseptual'nye podkhody $\mathrm{k}$ opredeleniiu soderzhaniia obrazovaniia $\mathrm{v}$ otechestvennoi didaktike]. Language and culture: issues of modern Philology and methods of teaching languages at university: Proceedings of research and practice conference [Iazyk i kul'tura: voprosy sovremennoi filologii i metodiki obucheniia iazykam v vuze: materialy nauchno-prakticheskoi konferentsii], 109-115, Khabarovsk, Russia.

Petukhova, I.A. (2018) Development of students' verbal and cogitative reflection in the course of educational and professional activity [Petukhova, I.A. Razvitie rechemyslitel'noi refleksii studenta $\mathrm{v}$ protsesse uchebno-professional'noi deiatel'nosti]. Topical issues of Pedagogy and Psychology at the present time [Aktual'nye problemy pedagogiki i psikhologii na sovremennom etape], 117-123, Volgograd, Russia.

Shennon, K. (1963) Works on information theory and cybernetics [Shennon, K. Raboty po teorii informatsii i kibernetike], 830, Moscow, Russia. 
Tsupikova, E.V. (2014) The basic trends of cognitive information processing: constructing the algorithms for text perception, recognition and analysis of message in students' thinking development process [Tsupikova, E.V. Osnovnye napravleniia myslitel'noi obrabotki informatsii - postroenie algoritmov vospriiatiia, opoznaniia, analiza soobshcheniia v rabote po razvitiiu myshleniia studentov]. Omsk Scientific Bulletin [Omskii nauchnyi vestnik], 3 (129), 197-201.

Vladimirova, L.P. (2016) The problems of teaching foreign languages in the era of globalisation [Vladimirova L. P. Problemy obucheniia inostrannym iazykam v epokhu globalizatsii]. PNRPU Linguistics and Pedagogy Bulletin [Vestnik Permskogo natsional'nogo issledovatel'skogo politekhnicheskogo universiteta. Problemy iazykoznaniia i pedagogiki], 3, 107-116

Vygotskii, L.S.(1982-1984) Thinking and speech; in 6 volumes [Vygotskii L. S. Myshlenie i rech': sobranie sochineniy v 6 t], vol. 2., 504, Moscow, Russia.

Zhinkin, N.I. (1982) Speech as information conductor [Zhinkin, N. I. Rech' kak provodnik informatsii], 159, Moscow, Russia.

Zimnyaya, I.A. (1985) Personality and activity approach in teaching Russian as a foreign language [Zimnyaya, I.A. Lichnostno-deiatel'nostnyi podkhod v obuchenii russkomu iazyku kak inostrannomu]. Russian language abroad [Russkii iazyk za rubezhom], 5 (97), 49-53, Moscow, Russia.

* This paper has been support by the RUDN University Strategic Academic Leadership Program. 